\title{
LEARNING IN PESANTREN AND INTERDEPENDENCE: NEWS ASPCETS OF RELIGIOUS EDUCATION IN SOUTH SULAWESI
}

\author{
Cholichul Hadi \\ Universitas Airlangga, Surabaya, Indonesia \\ Cellphone:+62-82233124028, Fax+62-31-5025910 \\ Email: cholichul.hadi@psikologi.unair.ac.id \\ Ismail Suardi Wekke \\ Sekolah Tinggi Agama Islam Negeri (STAIN) Sorong, West Papua, Indonesia \\ E-mail: iswekke@gmail.com
}

Presented in An ASEAN Psychology Conference, Faculty of Psychology Universitas Airlangga in Surabaya, Indonesia this November 19-21, 2015

\begin{abstract}
In Pesantren of Psychological health is the ability to develop, maintain, and appropriately modify interdependent relationships with others tosucceed in achieving goals' To manage social interdependence, individuals must correctly perceive whether interdependence exists andwhether it is positive or negative, be motivated accordingly, and act in ways consistent with normative expectations for appropriate behavior within the situation. Four studies have directly measured the relationship between social interdependence and psychological health. The samples studied included student and worker in suburban, village and city, In the recent millenium, it cannot be denied thatall of the part of the world are multicultural. It can be seen in the reality of society that there are diverse cultural backgrounds. Theconclusion also can be seen in Indonesian society. Indonesian society is a truly multicultural society. The fact can be seen in the diversityof the multicultural background in the Indonesian society
\end{abstract}

Science is a part of concerned in pesantren (Islamic boarding school) pedagogy. Therefore, it is emerge to create an environment that is equally empowering and mediating santris' (students) experiences in the classroom activities. In addition, gender and education are not easy issues because in order to facilitate teaching from theory to realities and practices need a comprehensive policy and understanding the whole part of education since culture and stereotype on gender are parts of life. PROBLEM: This study tries to find out the learning science in pesantren and how the learning processes relate to gender perspective. Furthermore, the paper investigates how did approaches and techniques that the pesantren apply to teach science. FINDING: As a result, the main research problem is what the characteristics of the learning science on education process in pesantren in term of gender equality awareness are. METHOD:This study was a qualitative exploration on experimental class. Non participant observation, depth interview and documentation review are performed to collect data from the subject 
research. The research was conducted in two pesantrens in Makassar. The pesantrens located in South Sulawesi province, eastern part of Indonesia. The research shows ustadz (teachers) motivate students to read material subject by the themes of cultural text. The activities enhance the values of the students original views. CONCLUTION: Next, it is a new aspect was providing the students with a lot directions for appreciating other cultures. The focus was on the skills where students were having a new technique in mastering science through understanding importance and sensitivity of other traditions and societies. A great deal of wide range of multicultural wil create a platform for students to enjoy realities and examine their own strengths and weakness. Finally, it promotes students' self confidence and enhance their acquitions of knowledge and culture.

Key word: Interdependence, Learning in Pesantren, Psychological health.

\section{I.INTRODUCTION}

In general, Indonesia's educational system still faced a shortage of resources in the 1990s. The shortage of staffing in Indonesia's schools was no longer as acute as in the 1950s, but serious difficulties remained, particularly in the areas of teacher salaries, teacher certification, and finding qualified personnel. Providing textbooks and other school equipment throughout the farflung archipelago continued to be a significant problem as well.

At the initial stage of the second long-term development plan, starting in 1994/1995, emphasis was given to human resources development in all sectors and sub-sectors of the national development. Therefore the development of national education cannot be separated from elements that can affect development, such as (1) the importance of value added orientation, (2) changes in the social structure, and (3)- effect of the globalization process. Based on that, emphasis should be given to the teaching of and the use of science and technology in education. (State Ministry of Women's Empowerment. 2001)

Since the nine years basic compulsory education was introduced in 1994, all efforts were focused to increase participation rate and improve quality of primary and junior secondary education. Data of the Ministry of National Education shows that in the mid 1980 's a large gender gap still existed at primary and junior secondary schools which in the 1990's narrowed to only 1\%-2\%. Girls performed better once enrolled in primary school resulting in higher progression rates. Data of 1999 shows that $25.6 \%$ and $28.2 \%$ boys and girls in urban areas finished primary school, while in the rural areas the percentage of girls who finished primary education is $34.8 \%$ compared to $37.7 \%$ boys. Both in urban and rural areas the percentage of girls not sent to school and not finishing primary school is higher than boys.

At the junior secondary school, the percentage of girls who graduated is lower than the percentage of boys. It is similar in urban as well as in rural areas. This may be due to the traditional belief that girls do not need to pursue high education because they are going to become housewives and have to take .care of the children. 
The emphasis on the Pancasila in public schools has been resisted by some of the Muslim majority. A distinct but vocal minority of these Muslims prefer to receive their schooling in a pesantren or residential learning center. (Ministry of National Education. 2001) In order for students to adapt to life in the modern, secular nation-state, the Muslimdominated Department of Religious Affairs advocated the spread of a newer variety of Muslim school, the madrasa. In the early 1990s, these schools integrated religious subjects from the pesantren with secular subjects from the Western-style public education system. The less-than 15 percent of the school-age population who attended either type of Islamic schools did so because of the perceived higher quality instruction. However, among Islamic schools, a madrasa was ranked lower than a pesantren. Despite the widespread perception in the West of resurgent Islamic orthodoxy in Muslim countries, the 1980s saw little overall increase in the role of religion in school curricula in Indonesia Usually in rural areas and under the direction of a Muslim scholar, pesantren are attended by young people seeking a detailed understanding of the Quran, the Arabic language, the sharia, and Muslim traditions and history. Students could enter and leave the pesantren any time of the year, and the studies were not organized as a progression of courses leading to graduation. Although not all pesantren were equally orthodox, most were and the chief aim was to produce good Muslims.

\section{II.PROBLEM}

This study tries to find out the learning science in pesantren and how the learning processes relate to gender perspective. Furthermore, the paper investigates how did approaches and techniques that the pesantren apply to teach science.

\section{METHOD}

This study was a qualitative exploration on experimental class. Non participant observation, depth interview and documentation review are performed to collect data from the subject research. The research was conducted in two pesantrens in Makassar. The pesantrens located in South Sulawesi province, eastern part of Indonesia. The research shows ustadz (teachers) motivate students to read material subject by the themes of cultural text. The activities enhance the values of the students original views

\section{FINDING AND DISCUSSTION}

1. Indonesia is the largest archipelago in the world and is situated between two continents, Asia and Australia and between two oceans, the Pacific and the Indian oceans. About 6,000 of the 13,667 islands and islets are inhabited by the population of 210 million of which $50.7 \%$ are female. Although the government does not have any regulations to discriminate women in education, employment and politics, there is a significant difference in the number of women compared to men in many positions in government, private organizations and in politics.( Ministry of Education and Culture. 1994)

2. In the year 2000, the President of Indonesia issued a Presidential Instruction (Inpres no 9/2000) on Gender Mainstreaming in National Development. Its Implementation Guidelines was issued in 2001 by the State Ministry of Women's Empowerment. With the guidelines, the Ministry of National Education started to 
socialize gender mainstreaming to all officials within the Ministry. Several workshops were held to insert gender mainstreaming in existing programs and in planning of new programs.

In the National Education Program 2000 (Propenas 2000) was mentioned that reformulation of education policy to become gender responsive has to be done, as follows:

1. Expansion and equalization of education opportunities

2. Upgrade academic competencies and professionalism of teachers and improve their prosperity

3. Improve the education system, including diversification of curriculum to meet the different needs of students

4. Empower all educational institutions so that values, attitude and competencies become their institutional culture

5. Improve the education system based on decentralization principle, autonomy of science and management

6. Improve the quality of public and private educational institutions

7. Develop the quality of human resources through various activities conducted by all components of the nation

To implement the policies several development programs for the education sector were established: (1) Preschool and Basic Education program, (2) Secondary Education program, (3) Higher Education program, (4) Out of School Education program, (5) Synchronization and Coordination of Education Development Programs, (6) Research and Capacity Building program, (7) Development of Resources for Science and Technology program, and (8) Improvement of Independence and Excellence in Science and Technology. (EFA Working Group. 2001)

\section{DISCUSSTION}

1. NU is the largest Muslim association in the world. It represents a more moderate form of Islam than the other large Indonesian Muslim movement, Muhammadiyah, which tends to have a more reformist outlook. NU is known particularly for its network of boarding schools, known as pesantren. It is tolerant of other spiritual practices, particularly Kejawan, which is rooted in the pre-Islamic culture of South Central Java.

2. As chairperson of NU, Abdurrahman Wahid pointed to NU's vision of development being encapsulated in the five basic human rights derived from the Koran and the Hadith: the rights to one's religion, to think for and to express oneself, to life, to livelihood and property and to have a family life. This vision is far broader than a vision of development as meaning merely a certain level of income or consumption and it is very different from the vision of the government of President Suharto (1966), which was all too ready to sacrifice people's rights for national economic development. For NU, destitution and lack of rights are the major problems, rather than poverty.

3. Another major problem was the Suharto government's imposition of a family planning programme supported by the United States and carried out without the women's consent, in order to raise the nation's economic standards. Since the government's main concern was that the population should decrease, the most convenient contraceptives, such as a 
three-monthly injections or IUD were promoted. This led to a great deal of fear and many accidents among women, who were not even informed about how these contraceptives worked. The necessary education and knowledge needed to exercise one's rights is one of NU's prime concerns.

4. NU sees development as the right of all people: "the spreading of the blessings that Allah has for everyone". Within NU there is no idea of experts and managers as opposed to beneficiaries. Since the aim is to educate individuals so that they can decide what to do with the knowledge they have gained, everyone is a beneficiary.

5. The (younger) women of NU Fatyat refer to the supreme aim of their work being to "satisfy the inner self". The essential notion is that experts and managers are themselves transformed by their work and thus the relationship of expert to beneficiaries breaks down.

6. NU has had close contact with the government and exercised considerable influence over its policies. The government soon realised that it was failing to enforce its family planning programme, in spite of being aided in its efforts to do so by the police and the military, and that it would need the help of NU if it were to achieve more success. NU then became involved with the National Coordinating Committee for Family Planning and managed to transform the government strategy into one focused on the care of mothers and children. This meant that the exclusive concern with numerical targets was changed to include support for women's education and reproductive rights.

7. The NU Muslimat (women over 40) was highly influential in persuading the (male dominated) NU to issue a fatwa that encouraged family planning in specific circumstances for the sake of family welfare (rather than to reduce the birth rate). Initially the NU leaders had been opposed to family planning because of the fear of reducing the numbers of adherents to the Islamic faith, but the women's voice was heard and their position understood.

8. The kyai (NU scholars of Islam) at first campaigned against family planning and many still forbid contraception as being "against God's will" but some have changed their views. This has been of the utmost importance in promoting the government's programme, since the people in rural areas trust the kyai and have a far closer relationship to them than to the government. Once the kyai are in agreement, they will allow programmes to be conducted through the pesantren and in the areas around them.

9. In the year 2000, the Government of Indonesia adopted a decentralisation programme, which has meant that the funding from the National Co-ordinating Committee for family planning has been cut off. It is highly unlikely that local governments will continue to fund the programme, which is now being supported by the Ford Foundation.

In the ensuing discussion, the following points were made:

1. More rigid Wahabian ideas from Arabic countries have come in to Indonesia but the fact that NU is so firmly rooted in Indonesian culture has meant that it has remained strong.

2. The affirmation that Allah's blessings are for everyone means that NU intends to work for the whole of humanity, not just for NU people. For Abdurrahman Wahid, inclusiveness and inter-religious dialogue were of paramount importance. 
3. The women of the NU run 16 hospitals. Women prefer to go to them, even though they may be less well funded and equipped than state hospitals, because the health professionals who work in them speak in Islamic terms and help them to overcome their traumas.

4. The NU does not campaign on behalf of people's rights, though many of its members are organised to regain their rights, such as land.

5. The NU has not been co-opted by the government, though in 1984 it saw the danger of this and decided to remove itself from the political party arena. However it has accepted funding from all sorts of organisations, some of whose ideology differs considerably from its own. It is always a question of who is influencing whom?

\section{CONCLUTION}

The gender equality in basic education is being pursued in the Education for All (EFA) program and is still in progress. Delays in action was because of the economic crisis in 1997 which is not yet recovered. With the commitment of the government to provide a larger portion of the national state budget for education and to reach all school age children in the basic compulsory education program, there is hope that gender equality will also be reached in the formal education sector. In the out of school education, functional literacy education programs, especially for women, will be delivered through the Community Learning Centers (CLQ).

The question was asked how Islam can be compatible with democracy if the ruler is seen as Allah's vice-regent and the government as the custodian of the will of Allah.

Abdus explained that unfortunately there is no perfect example of a democracy but the Prophet listened to people and only then tried to give sensible advice. He favoured those who do good over those who pray and ignore the need around them. By marrying a widow who was no longer young, he showed the importance of respecting the wisdom of women. There is no conflict between Islam and democracy or human rights. On the contrary, the overriding principles of Islam include love and inclusiveness.

The problem is the lack of wisdom in our leaders of all religions, which stems from a lack of awareness. We can learn from poor people. We all need education but the way we are being educated leads us to serve powerful corporations rather than people. Most people in high places are highly educated but they have the wrong values.

There are people who have been educated who return to their communities and give back what they have learnt in return for the "milk and mangos" they received as children. But as communities become more sophisticated, such values tend to be forgotten. People can be empowered by tradition and faith, not only by money, but their capacities need to be built up for faith to survive and to make a contribution to the development of a caring society.

Pesantren in suburban, village and city. The results indicated that (a) workingcooperatively with peers and valuing cooperation result in greater psychological health than does competing with peers or working 
independently and (b) cooperative attitudes are highly correlated with a wide variety of indices of psychological health, competitivenesswas in some cases positively and in some cases negatively related to psychological health, and individualistic attitudes were negativerelated to a wide variety of indices of psychological health. Cooperativeness is positively related to a number of indices of psychologicalhealth, such as emotional maturity, well-adjusted social relations, strong personal identity, ability to cope with adversity, socialcompetencies, and basic trust in and optimism about people. Personal ego-strength, self-confidence, independence, and autonomy areall promoted by being involved in cooperative efforts

\section{SUGGESTION:}

1. We should circulate more examples of good practice, which means collecting up more stories and examples

2. We should share our calendars of events so that we can attend each other's wherever possible.

3. We should try to get sponsorship for internships for young people so that they can go and learn from other experiences

4. We should use this network to mobilise support when we need it, eg for petitions

5. In the spiritual dimension of their work and ask how we might engage with them.

6. We need to provide more training materials for people so that they can understand the relevance of their religion in facing the problems of the modern age.

7. We should look at the possibility of inserting the topic of spirituality and development into existing courses on development issues.

8. The meeting ended with expressions of gratitude to the many people involved in the organisation of the workshop, as well as those who had taken the time and trouble to participate in what was generally agreed to have been a very interesting and inspiring event.

9. We are not talking of either only spiritual or only material development. Well-being is the application of spiritual values and belief in inner transformation. Once we have individuals in society who have these values, they can act as change agents but it will only happen when we have unity among the different faith traditions. We need this unity not merely to provide a united face to the World Bank and other institutions but internally, for ourselves.

10. Negative forces may not be able to be removed from the system but we have to increase positive forces. This is only possible if people of faith with spiritual values stand together.

11. Our purpose of solidarity is to establish peace and justice in society. If we are united we can do this on behalf of and with the poor and the oppressed. Through carrying out advocacy for the poor we are also transforming ourselves. We have to do some work with our own organisations but there are areas in which we can work together.

12. The way we network is important, as the bigger networks become, the more difficult it is to make them effective and the actual networking can take up a lot of time.

13. The issue of not leaving out people of more fundamentalist and rigid views was again discussed, though it was recognised that more progressive networks are needed as spearheads for action and also that it is not a question of getting huge numbers involved. "It is the greatness of the idea that is important". 
14. We need to be very clear about our statement of principles, as there is a fear that interfaith movements are really wanting to merge us all and pretend we are all saying the same thing.

\section{REFERENCE}

EFA Working Group. 2001. Education for All National Action Plan 2001-2015. National Consultative Meeting, 29 August- 1 September 2001 (in Bahasa Indonesia).

Ministry of Education and Culture. 1994. The Development of Education System in Indonesia. A Country Report.

Ministry of National Education. 2001. Universal Basic Education: The Roles of Distance Education and Policy Implications. Presented at the E9-Ministerial Review Meeting in Beijing, 21 - 23 August 2001.

National Planning Agency (Bappenas) and WSP II-CIDA. 2001. Gender Analysis in Educational Development (in Bahasa Indonesia).

State Ministry of Women's Empowerment and Women Support Project II/CIDA. 2001. Gender Mainstreaming, a Strategy in Development (in Bahasa Indonesia).

State Ministry of Women's Empowerment. 2001. Gender Analysis in Education Development (in Bahasa Indonesia). Jakarta.

State Ministry of Women's Empowerment. 2001. Implementation Guidelines for Inpres No 9/2000 on Gender Mainstreaming in National Development in Bahasa Indonesia, Jakarta.

Wekke, I, and Hadi.,C. Learning Science In Pesantren: A Strategy to Support Gender Awareness SEAMEO RECSAM, Penang, Malaysia,November13 - 16, 2007. Presented in The 2nd International Conference on Science and Mathematics Education. 